\title{
Sarcocystis cristata sp. nov. (Apicomplexa, Sarcocystidae) in the imported great blue turaco Corythaeola cristata (Aves, Musophagidae)
}

Ondřej Máca ${ }^{1,2}$ and David González-Solís $3^{*}$

\begin{abstract}
Background: Species of Sarcocystis are parasitic protozoa in poikilothermic and homeothermic animals. Out of the 26 valid species in birds as intermediate hosts, none has been reported in those of the order Musophagiformes, such as the great blue turaco Corythaeola cristata (Vieillot, 1816), which is a bird endemic to Central and Western Africa. The examination of great blue turacos imported from the Central Africa Republic to Czech Republic allowed the morphological and molecular characterization of a new species of Sarcocystis.
\end{abstract}

Methods: Four turacos imported from the Central Africa Republic to a private breeder (Czech Republic) underwent parasitological examination for the presence of sarcocysts through wet mounts of breast, heart and leg muscles. Found parasites were molecularly and histologically studied by four loci (18S rRNA, 28S rRNA, ITS1 and cox1) and haematoxylin and eosin staining, respectively.

Results: Three out of four examined birds harboured numerous sarcocysts in the breast and leg muscles. No macroscopic lesions where observed. Sarcocysts were microscopic, elongate and ribbon-shaped with a wall characterised by the presence of finger-shaped villar protrusions and filled with numerous elongate, banana-shaped bradyzoites, 11.87-14.84 × 2.05-2.92 $\mu \mathrm{m}$ in size. The new species was most closely related to Sarcocystis albifronsi, Sarcocystis anasi, Sarcocystis atraii, Sarcocystis chloropusae, Sarcocystis rileyi, Sarcocystis wenzeli and Sarcocystis sp. isolate from chicken in the four loci.

Conclusions: To our knowledge, this is the first species of Sarcocystis found in a musophagiform bird worldwide. Genetically, S. cristata sp. nov. represents a distinct species. Phylogenetic analyses are useful for predicting potential definitive hosts of the new Sarcocystis species.

Keywords: Africa, Sarcocystis, Aves, Molecular characterization, New species

\section{Background}

Species of the genus Sarcocystis Lankester, 1882, are parasitic protozoa with an indirect life cycle using poikilothermic and homeothermic animals as definitive and intermediate hosts. The latter includes mammals, birds, marsupials and poikilothermic animals where most

*Correspondence: dgonzale@ecosur.mx

${ }^{3}$ El Colegio de la Frontera Sur, Chetumal. Av. Centenario km 5.5, 77014 Chetumal, Quintana Roo, Mexico

Full list of author information is available at the end of the article sarcocysts are found in the striated muscles of the heart, tongue, oesophagus, diaphragm and skeletal muscles as well as in the smooth muscles of intestine [1]. To date, 16 bird orders (e.g. Anseriformes, Galliformes, Passeriformes, etc.) have been reported worldwide as intermediate hosts of 40 species of Sarcocystis, of which 26 are valid, while the rest are invalid or species inquirendae [1, present paper]. However, there still are no records of sarcocysts in birds of the order Musophagiformes, such as the great blue turaco Corythaeola cristata (Vieillot, 1816) (Musophagiformes, Musophagidae), which is a 
bird endemic to Central and Western Africa. It has been scarcely parasitologically studied, with records mostly on haematozoan parasites (genera Haemoproteus, Leucocytozoon, Microfilaria and Trypanosoma) [2-8], but nothing on Sarcocystis. During the examination of great blue turacos imported from the Central Africa Republic to Czech Republic, sarcocysts of an apparently new species of Sarcocystis were found in the breast and legs muscles. The morphological and molecular characterization of those specimens is presented here as well as the role as an intermediate host in the life cycle of a Sarcocystis species.

\section{Methods}

In 2019, four frozen turacos in poor body condition were sent to the State Veterinary Institute (SVI) Prague for necropsy. These birds were imported from the Central Africa Republic to a private breeder (Czech Republic) where they died after $\mathrm{s}$ few days in quarantine. Later, the birds were examined for parasites under light microscopy (LM) through wet mounts of breast, heart and leg muscles for the presence of sarcocysts. The flotation method was also used to detect the presence of parasites in the digestive tract. Both methods were carried out using a Leica DMLB optical microscope with a Leica DFC420 digital camera (Leica Microsystems, Wetzlar, Germany) equipped with Nomarski differential interference contrast. Found parasites were transferred to Eppendorf tubes for DNA extraction. For histology, muscles with sarcocysts were fixed in 10\% formalin solution, and tissue sections were stained with haematoxylin and eosin. All measurements are given in micrometres, unless otherwise mentioned.

Genomic DNA was extracted by glass bead disruption from six isolates of sarcocysts collected from breast and leg muscles using the QIAamp ${ }^{\circledR}$ Fast DNA Stool Mini Kit (Qiagen, Hilden, Germany) according to the manufacturer's recommendations. DNA was stored at $-20^{\circ} \mathrm{C}$ until use in polymerase chain reaction (PCR) assays of $18 S$ rRNA, $28 S$ rRNA, ITS1 and cox 1 loci. PCR and nested-PCR were carried out by using primers for $18 \mathrm{~S}$ rRNA (A2F/Primer BSarc and Fext/Rext; Fint/Rint) [9, 10], $28 S$ rRNA (KL_P1R/KL_P1F and KL1/LS2R; LS1F/ KL3) [11-13], ITS1 region (ITS-F/ITS-R; SU1F/5.8SR2) $[11,13]$ and $\operatorname{cox} 1$ genes (SF1/SR10 or SF1/SR5) $[14,15]$. Amplification was carried out in a final volume of $25 \mu \mathrm{l}$ (20 $\mu \mathrm{l}$ reaction mixture and $5 \mu \mathrm{l}$ DNA extract) comprising $1 \times$ Green GoTaq $^{\circledR}$ Flexi Buffer, $2.5 \mathrm{mM}$ of $\mathrm{MgCl}_{2}$, $0.625 \mathrm{U}$ of $\mathrm{GoTaq}^{\circledR}$ G2 Flexi DNA Polymerase (Promega, Madison, WI, USA), $0.2 \mathrm{mM}$ dNTP mix (Bioline, London, UK) or GoTaq ${ }^{\circledR}$ G2 Colorless Master Mix (Promega, Madison, WI, USA), $0.4 \mu \mathrm{M}$ of each primer, DNA template and nuclease-free water. PCR amplification of isolated DNA samples plus positive and negative controls was performed with the following cycling conditions: an initial denaturation step at $95{ }^{\circ} \mathrm{C}$ for $5 \mathrm{~min}$; 35 cycles of $95{ }^{\circ} \mathrm{C}$ for $30 \mathrm{~s}, 52-60{ }^{\circ} \mathrm{C}$ for $30 \mathrm{~s}$ and $72{ }^{\circ} \mathrm{C}$ for $1 \mathrm{~min}$; a final extension step at $72{ }^{\circ} \mathrm{C}$ for $10 \mathrm{~min}$. The PCR products were later analysed by electrophoresis in $1-1.5 \%$ agarose gel and visualised by ethidium bromide staining. The PCR products were purified using the High Pure PCR Product Purification Kit (Roche Diagnostics, Mannheim, Germany) or the ExoSAP-IT ${ }^{\mathrm{TM}}$ Express PCR Product Cleanup Reagent Kit (Thermo Fisher Scientific) according to the manufacturer's protocol. Cleaned amplicons were sequenced through the commercial company Eurofins Genomics (Ebersberg, Germany) using both forward and reverse primers. The nucleotide sequences of the four loci derived in this study have been deposited in the GenBank database under accession numbers MT676453-MT676455 and MT681118.

The newly generated sequences were analysed and edited using FinchTV software (Geospiza Inc., Seattle, WA) and compared with published sequences of the valid species of Sarcocystis across the GenBank NCBI database using BLAST (Basic Local Alignment Search Tool). Sequences were aligned using MAFFT software version 7 [16], and phylogenetic trees were constructed using the MEGA X [17]. The neighbour-joining (NJ) method and Tamura three-parameter model were used for $18 \mathrm{~S}$ rRNA and $\operatorname{cox} 1$ genes, while the maximum likelihood method (ML) and Hasegawa-Kishino-Yano model were used for the $28 S$ rRNA gene and ML and Tamura-Nei model for the ITS1 region. For the NJ method, evolutionary distances were computed using the Tamura three-parameter method $(\mathrm{T} 92+\mathrm{G})$ from the selected 1716 aligned positions with 19 nucleotide sequences of $18 \mathrm{~S}$ rRNA and from the selected 1013 aligned positions with 18 nucleotide sequences of $\operatorname{cox} 1$ gene. For ML, they were performed by applying the Hasegawa-Kishino-Yano model $(\mathrm{HKY}+\mathrm{G}+\mathrm{I})$ from the selected 1330 aligned positions with 23 nucleotide sequences for the $28 s$ rRNA gene and Tamura-Nei model (TN93 + G + I) from the selected 1460 aligned positions of 23 nucleotide sequences for the ITS1 region. A bootstrap test of phylogeny was computed based on 1000 replicates for all loci, and NJ and ML trees were rooted with Toxoplasma gondii.

\section{Results}

Three out of four examined birds (prevalence: 75\%) harboured at least one sarcocyst. No macroscopic lesions were observed in the organs of infected birds. However, sarcocysts were found in breast and leg muscles in similar numbers (three sarcocysts per gram). Heart muscles of all birds were negative. No gastrointestinal parasites were found. Sarcocysts were described as follows: 
Family Sarcocystidae Poche, 1913

Sarcocystis cristata sp. nov. (Figs. 1, 2)

Description: Microscopic, elongate, ribbon-shaped sarcocysts (Fig. 1a). The longest sarcocyst is 1348 long and 40 wide. Anterior and posterior ends rounded. The sarcocyst wall was characterised by the presence of finger-shaped villar protrusions, 2.6 long (Fig. 1b, d). Mature sarcocyst packed with some metrocytes and plenty of elongate, banana-shaped bradyzoites, 11.87$14.84 \times 2.05-2.92$ in size $(n=30)$ (Figs. 1c, 2a). There are some pyknotic nuclei around the sarcocyst, but without an apparent inflammatory reaction (Fig. 2a, b).

\section{Taxonomic summary}

Intermediate host: Great blue turaco Corythaeola cristata (Vieillot, 1816) (Musophagidae).

Definitive host: Unknown.

Original distribution: Central Africa Republic.

Deposited material: Symbiotype (frozen muscle with sarcocysts) and genomic DNA in Eppendorf tube were stored at SVI Prague. GenBank sequences MT676454 (18S rRNA gene), MT676455 (28S rRNA gene), MT676453 (ITS1 region), MT681118 (cox1 gene).

ZooBank registration: To comply with the regulations set out in article 8.5 of the amended 2012 version of the International Code of Zoological Nomenclature [18], details of the new species have been submitted to ZooBank. The Life Science Identifier (LSID) for Sarcocystis cristata sp. nov is urn: lsid:zoobank. org:pub:38C58A60-08C1-4CAD-B02F-A0C9B812E2B4

Etymology: The specific epithet is derived from the species name of its intermediate host, i.e. cristata.

Molecular sequences of the $18 S$ rRNA, $28 S$ rRNA, ITS1 and cox 1 loci from six sarcocyst isolates were successfully obtained with no intraspecific variability. Those sequences of $18 S$ rRNA were identical; therefore, only one of 1611 bp was submitted to GenBank (MT676454). Blasting showed high similarity between the $18 S$ rRNA sequence of $S$. cristata sp. nov. and those of S. anasi, S. albifronsi and S. wenzeli (99.8\% each) in the mallard duck (Anas platyrhynchos) (EU553477), the white-fronted goose (Anser albifrons), both from Lithuania (EU502868) and chicken (Gallus gallus) from China (MT756990), respectively; Sarcocystis sp. isolate from chicken (most likely S. wenzeli, see [19]) (99.7\%) from Brazil (MN845627); S. rileyi (99.5\%) in the common eider (Somateria mollissima) in Norway (KJ396583); S. atraii and S. chloropusae (99.2\% each) in the common coot (Fulica atra) (KJ810606) and the common moorhen (Gallinula chloropus) (KJ810604), respectively, both from Egypt. The $28 \mathrm{~S}$ rRNA locus (1350 bp) was most similar to those of $S$. wenzeli (99-99.2\%) (MT756986-8), S. albifronsi (98.8\%)
(EF079885), S. anasi (98.7\%) (EF079887), S. chloropusae (97.9\%) (KJ810605), S. rileyi (97.2\%) (KJ396585) and S. atraii (96.6\%) (KJ810607). While sequences of the ITS1 region (1090 bp) were most similar to $S$. wenzeli (92.5-92.8\%) (MT756994-7), Sarcocystis sp. isolate from chicken (91.2\%) (MN846302), S. anasi (89.5\%) (JF520779), S. albifronsi (88.4\%) (JF520780), S. chloropusae (80.5\%) (KJ810610), S. rileyi (78.2\%) (KJ396584) and $S$. atraii (69.2\%) (KJ810611). The cox1 sequence (1013 bp) showed higher similarity to S. albifronsi (99\%) (MH138310), S. anasi (98.7\%) (MH138311), S. wenzeli (97.9\%) (MT761700), S. rileyi (97.2\%) (KJ396582) and Sarcocystis sp. isolate from chicken (97.1\%) (MN848337).

Phylogenetic analysis showed the relationships of the new species with other Sarcocystis spp. from birds as intermediate hosts. All four phylogenetic trees showed similar topologies regarding the formation of two groups, one formed mostly by $S$. calchasi, S. columbae, S. cornixi, S. corvusi, S. fulicae, S. halieti, S. lari, S. lutrae, S. turdusi and S. wobeseri and the second group with the new species and seven congeneric species (S. albifronsi, S. anasi, S. atraii, S. chloropusae, S. rileyi, $S$. wenzeli, Sarcocystis sp. chicken isolate). The position of S. cristata shows a stronger relationship with S. wenzeli and Sarcocystis sp. isolate chicken2016-DF-BR (Fig. 3c), although it is also closely related to $S$. albifronsi, S. anasi, S. atraii, S. chloropusae and S. rileyi (Fig. 3a-d). Sarcocystis atraii/S. rileyi and $S$. albifronsi/S. chloropusae are sister species (Fig. 3a, c).

\section{Discussion}

The thread-like shape of the present specimens and the asexual development in the striated muscles of the intermediate host, a heteroxenous life cycle and the presence of metrocytes and bradyzoites in the sarcocyst indicate that they belong to the genus Sarcocystis [20]. This parasite, despite the small sample size $(n=4)$, showed a relatively high prevalence in the examined birds, thus suggesting that its presence in turacos is possible and that the latter act as its natural intermediate host. This finding represents the first worlwide report of a Sarcocystis sp. in a member of the family Musophagidae.

As mentioned above, there are 26 valid species of Sarcocystis using birds as intermediate hosts, namely: $S$. accipitris Černá et Kvašňovská, 1986, S. albifronsi Kutkiené, Prakas, Sruoga et Butkauskas, 2012, S. alectoributeonis Pak, Sklyarova et Pak, 1989b, S. alectorivulpes Pak, Sklyarova et Pak, 1989b, S. anasi Kutkiené, Prakas, Sruoga et Butkauskas, 2012, S. atraii El-Morsey, ElSeify, Desouky, Abdel-Aziz, El-Dakhly, Kasem, Abdo, Haridy, Skai et Yanai, 2015, S. calchasi Olias, Gruber, Hafez, Heydorn, Mehlhorn et Lierz, 2010, S. chloropusae 

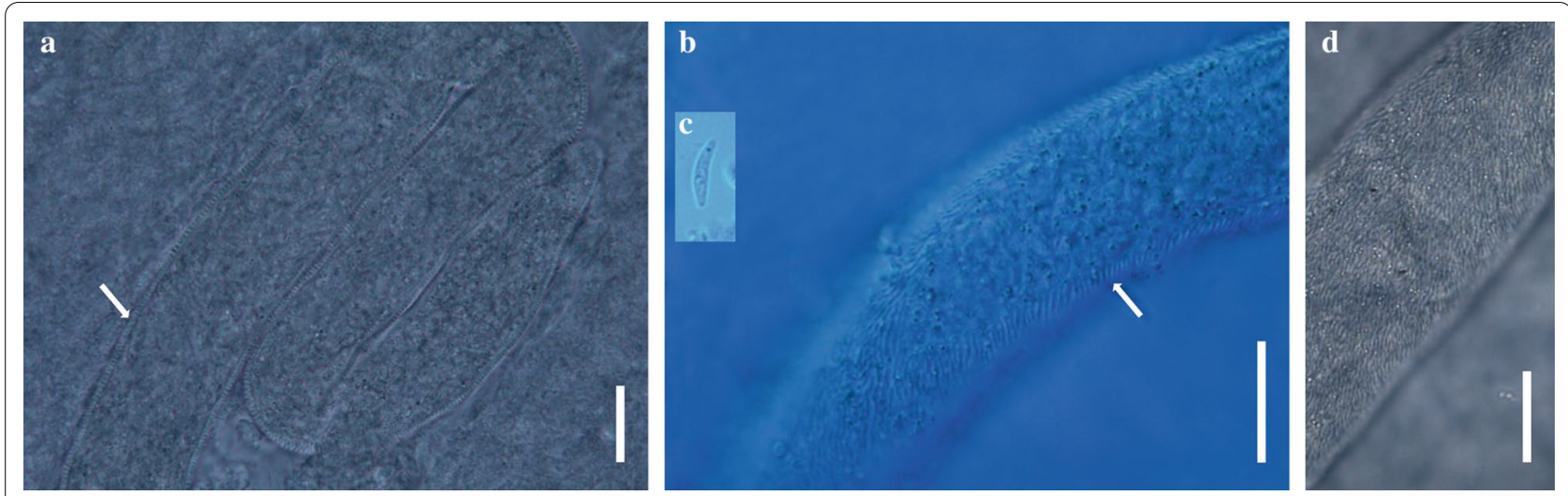

Fig. 1 Sarcocystis cristata sp. nov. from Corythaeola cristata, light micrographs (a, d) and Nomarski interference-contrast photomicrographs (b, c) of wet mount: a Sarcocyst in breast muscle of host; $\mathbf{b}$ fragment of released sarcocyst (arrows indicate sarcocyst wall with finger-shaped villar protrusions); c bradyzoite; $\mathbf{d}$ villar protrusions on middle part of sarcocyst. Scale bars $=20 \mu \mathrm{m}$
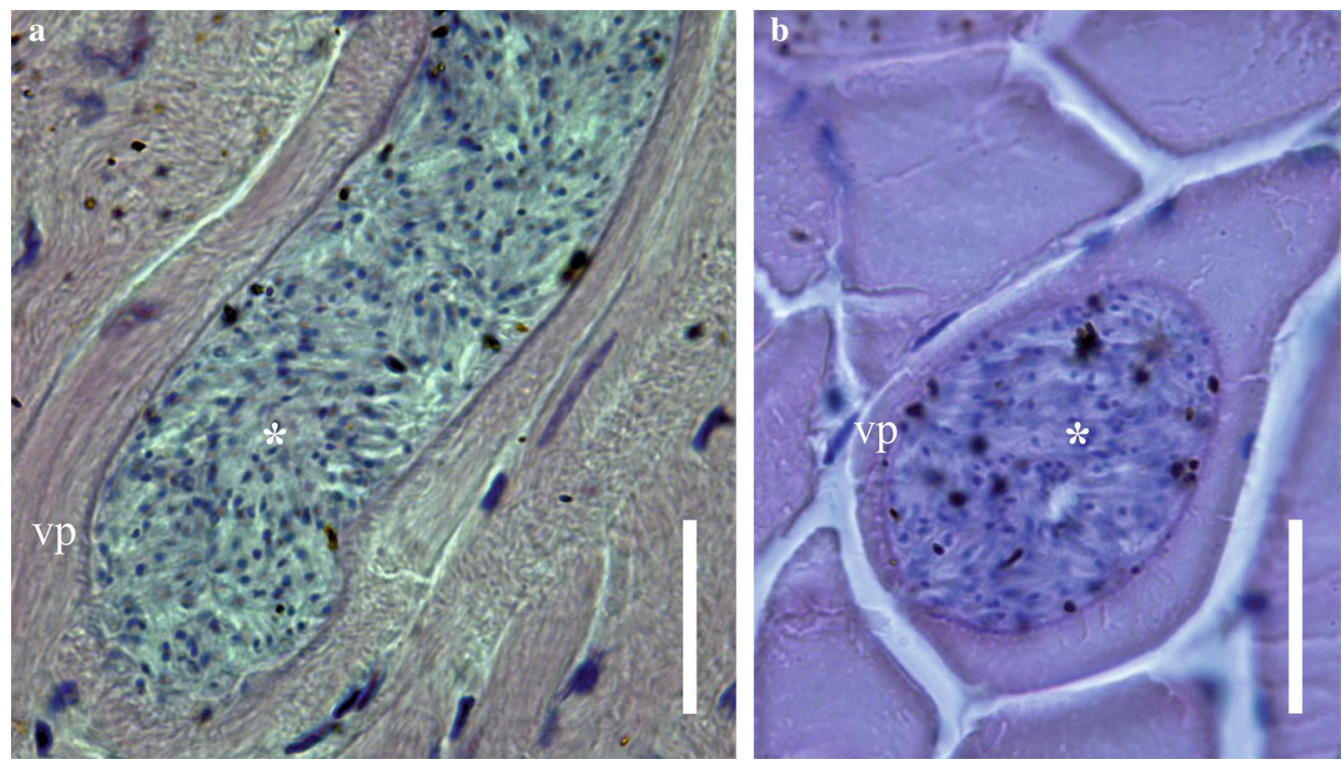

Fig. 2 Haematoxylin and eosin-stained histological sections of skeletal muscle from Corythaeola cristata: Longitudinal (a) and transversal (b) sections of sarcocyst, respectively; asterisks indicate sarcocyst packed with bradyzoites. $v p$ villar protrusions. Scale bars $=20 \mu \mathrm{m}$

El-Morsey, El-Seify, Desouky, Abdel-Aziz, Sakai et Yanai, 2015, S. columbae Olias, Olias, Lierz, Mehlhorn et Gruber, 2010, S. cornixi Kutkiené, Prakas, Sruoga et Butkauskas, 2009, S. corvusi Prakas, Kutkiené, Butkauskas, Sruoga et Žalakevičius, 2013, S. falcatula Stiles, 1893, S. fulicae Prakas, Butkauskas, Švažas, Juozaityté-Ngugu et Stanevičius, 2018, S. halieti Gjerde, Vikøren et Hamnes, 2018, S. horvathi Rátz, 1908, S. kirmsei Garnham, Duggan et Sinden, 1979, S. kutkienae Prakas, Butkauskas et Juozaityté-Ngugu, 2020, S. lari Prakas, Kutkiené, Butkaukas, Sruoga et Žalakevičius, 2014, S. lindsayi Dubey, Rosenthal et Speer, 2001, S. phoeniconaii Göbel, Erber et Grimm, 1996, S. ramphastosi Dubey, Lane et van Wilpe, 2004, S. rileyi (Stiles, 1893) Minchin, 1903, S. sulfuratusi Dubey, Lane et van Wilpe, 2004, S. turdusi Kutkiené, Prakas, Butkauskas et Sruoga, 2012, S. wenzeli (Wenzel, Erber, Boch et Schellner, 1982) Odening, 1997, and S. wobeseri Kutkiené, Prakas, Sruoga et Butkauskas, 2010. Most of these species were morphologically described and apparently differ from the new species in the size of the sarcocyst and wall ultrastructure, although the first might be variable according to its age and the second was not analyzed in this study with transmission electron microscopy.

Molecular analysis of the four loci supported the identification of the present sequences as belonging to a new species. Groups of related species in the phylogenetic 
trees were formed, in one, mostly by Sarcocystis spp. with a bird of prey (e.g. hawks, eagles) as definitive host [see e.g. 9, 21-25], while the second grouped the new species and others allegedly using mammals as definitive hosts, such as S. albifronsi in Arctic fox (Alopex lagopus) from Lithuania [26], S. anasi and S. rileyi in $V$. vulpes and racoon dog (Nyctereutes procyonoides) from Lithuania [27] and Germany [28], S. atraii probably in American mink (Neovison vison) and red fox (Vulpes vulpes) from Egypt [29], S. chloropusae maybe in V. vulpes [30] and S. wenzeli experimentally in dogs and cats [19]. With the most conclusive locus (ITS1 region), the clade formed by S. cristata sp. nov. with S. wenzeli and Sarcocystis sp. isolated from chicken is well supported and shows the close relationship of these species. Sarcocystis cristata is a separate species from Sarcocystis sp. isolated from chicken and $S$. wenzeli, which are the same species, as stated by Pan et al. [19]. The latter two species and five other congeners formed a recurrent group of species reported in several previous works [e.g. 24, 29], despite being of different sarcocyst wall type (S. albifronsi, S. anasi and $S$. wenzeli type 9, S. atraii type 24, S. chloropusae type 10 , S. rileyi type 23) and bird orders (e.g. Anseriformes, Galliformes, Gruiformes, Musophagiformes). Differences in the number and type of Sarcocystis species grouped with $S$. cristata sp. nov. are related to the availability of sequences in GenBank.

As mentioned above, the great blue turaco is a bird species endemic to West and Central Africa, where it apparently has few natural enemies. Therefore, the life cycle of $S$. cristata sp. nov. is unknown, but great blue turacos probably get infected after ingestion of sporocysts in food (leaves, buds, insects, flowers) or water, thus acting as intermediate hosts. Ants, cockroaches and crickets are food sources for many birds and can serve as paratenic hosts for internal parasites such as Sarcocystis [see 31]. The fact that the new species clustered with other avian Sarcocystis spp., whose definitive hosts are mammals, could indicate that some terrestrial carnivorous mammals (e.g. mongoose, linsang or side-striped jackal) might act as definitive hosts for it. These predatory mammals commonly occur in the same region and feed on arboreal
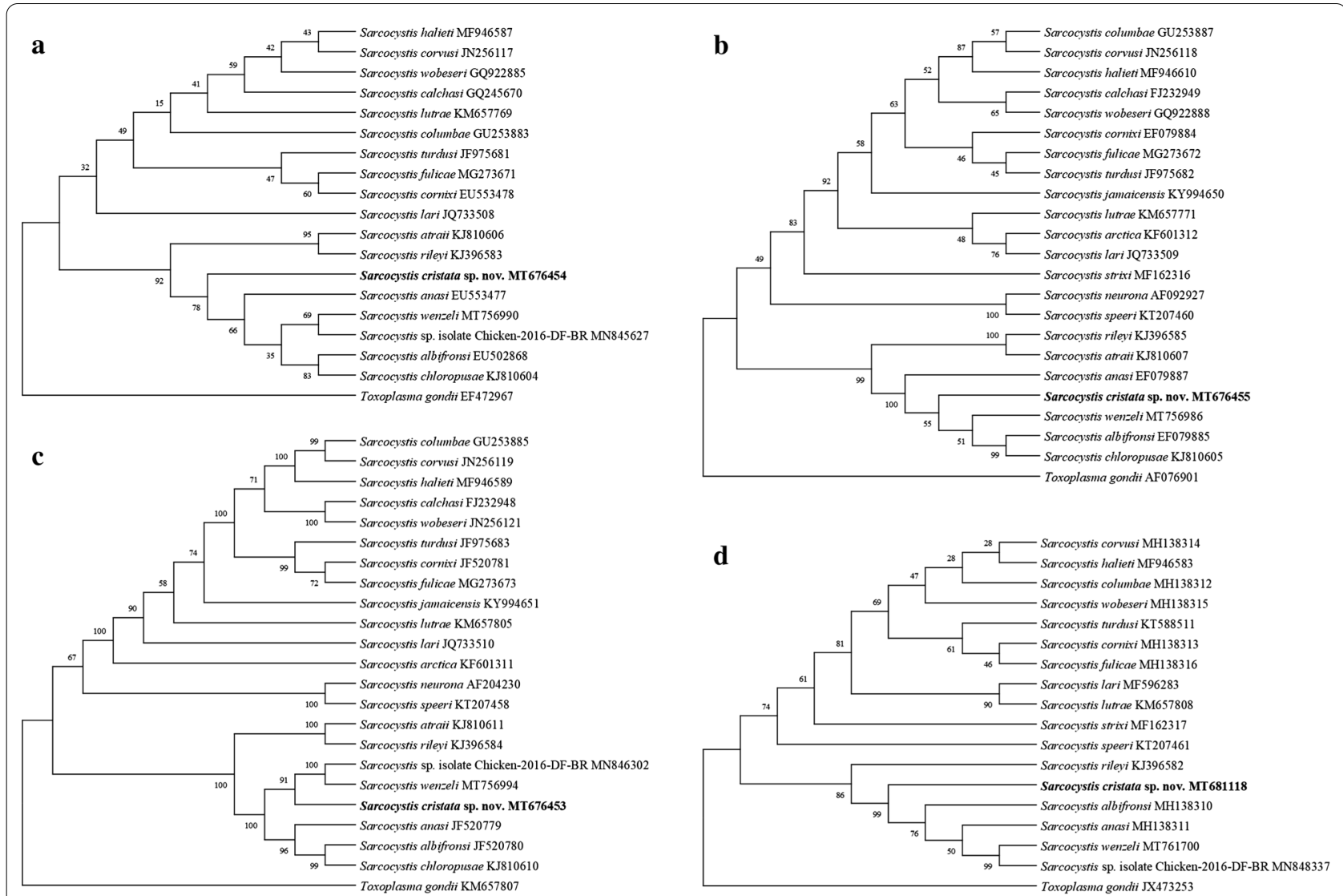

Fig. 3 Phylogenetic trees of the species of Sarcocystis from some avian and mammal hosts based on a 18S rRNA, b 28S rRNA, c ITS1 and d cox1 loci sequences. The numbers on phylogenetic trees represent bootstrap values based on 1000 replications. GenBank accession numbers follow Sarcocystis species 
birds, although nothing is known about their role as predators of turacos.

Shape, sarcocyst wall type and other morphological and morphometric data have been reported in almost all avian species, but they are insufficient to complete their specific identification [24]. In fact, Levine [20] wrote that "...the fine structure of the sarcocyst wall may change with age and is not considered necessarily satisfactory for separating species”. Recently, Prakas et al. [32] identified one morphological type of Sarcocystis in the herring gull Larus argentatus from Lithuania, but indeed it represented four different species. On the other hand, genetic markers have proved to be more reliable, although $18 \mathrm{~S}$ rRNA, 28S rRNA and cox1 were sometimes unable to separate species [see 9, 33]. For Sarcocystis species using birds as intermediate hosts, the ITS1 region was the most conclusive locus to clearly separate the new species from its congeners, while other loci were scarcely variable to distinguish species, although all genetic markers supported the designation of the new species. Apparently, the ITS1 region is more sensitive to the genetic differences among species, as mentioned by Prakas et al. [24] and Pan et al. [19], who also found a similar utility of molecular analysis while studying S. fulicae in Fulica atra from Lithuania and S. wenzeli in G. gallus from China, respectively.

The birds were probably infected before importation to Czech Republic, since they were in quarantine and then died. However, the presence of great turacos in zoos and private breeding facilities and their potential escape or release to the wild should be monitored, since these birds could spread sarcocysts to native carnivorous mammals in the region. The cause of death of turacos was neither determined, but the occurrence of Sarcocystis in birds should be diagnosed since related species, such as $S$. rileyi and Sarcocystis sp. isolated from chicken, have been reported as causing sarcocystosis in the skeletal muscle (rice breast) of ducks [34] and meningoencephalitis in the brain of chickens [35], respectively. Future studies may be focused on the proper parasitic diagnosis before importation, thus preventing the economic losses related to the trade of turacos around the world.

\section{Conclusions}

To our best knowledge, this is the first study focused on the sarcocysts of a musophagiform bird worldwide. Genetically, S. cristata sp. nov. from the great blue turaco represents a distinct species. Phylogenetic analyses are useful for predicting potential definitive hosts of the new species, although future studies should be focused on faecal or intestinal samples of possible native definitive hosts (mammals) to elucidate their role in the life cycles of Sarcocystis species.

\section{Abbreviations}

bp: Base pairs; cox1: Cytochrome c oxidase subunit 1; DNA: Deoxyribonucleic acid; ITS1: Internal transcribed spacer 1; NCBI: National Centre for Biotechnology Information; PCR: Polymerase chain reaction; rRNA: Ribosomal ribonucleic acid; sp. nov: New species.

\section{Acknowledgements}

The authors thank all colleagues from the Pathology and Parasitology Department (SVI Prague), mainly E. Dubská and V. Junová, for their technical support and a private breeder for providing valuable information. The graphical abstract was done in cooperation with O. Doskočil. This research was performed within the Centre for Infectious Animal Diseases. Thanks to to the three anonymous reviewers for their valuable, concise and precise suggestions.

\section{Authors' contributions}

OM, DGS conceived and designed the study, OM performed analyses, and OM, DGS wrote the manuscript. Both authors read and approved the final manuscript.

\section{Funding}

Open access funding was provided by the Faculty of Agrobiology, Food and Natural Resources, Czech University of Life Sciences Prague.

\section{Availability of data and materials}

The sequences generated in the present study were submitted to the GenBank database under the accession numbers MT676453-MT676455, MT681118.

\section{Ethics approval and consent to participate}

Not applicable.

\section{Consent for publication \\ Not applicable.}

\section{Competing interests}

The authors declare that they have no competing interests.

\section{Author details}

${ }^{1}$ Department of Pathology and Parasitology, State Veterinary Institute Prague, Sídlištní 136/24, 16503 Prague 6, Czech Republic. ${ }^{2}$ Department of Zoology and Fisheries, Faculty of Agrobiology, Food and Natural Resources, Czech University of Life Sciences Prague, Kamýcká 129, 16500 Prague Suchdol, Czech Republic. ${ }^{3}$ El Colegio de la Frontera Sur, Chetumal. Av. Centenario km 5.5, 77014 Chetumal, Quintana Roo, Mexico.

Received: 12 October 2020 Accepted: 13 December 2020 Published online: 18 January 2021

\section{References}

1. Dubey JP, Calero-Bernal R, Rosenthal BM, Speer CA, Fayer R. Sarcocystosis of animals and humans. Boca Raton: CRC Press; 2016.

2. Minchin EA. Report on a collection of blood-parasites made by the sleeping sickness commission, 1908-1909, in Uganda. Rep Sleep Sick Comm R Soc. 1910;10:73-86.

3. Hamerton AE. Report on the deaths occurring in the Society's gardens during the year 1930. Proc Zool Soc Lond. 1931;101:527-55.

4. Schwetz J. Sur quelques hématozoaires des oiseaux de Stanleyville (Congo Belge). Ann Parasit Hum Comp. 1931;9:311-22.

5. Schwetz J. Trypanosomes rares de la région de Stanleyville (Congo Belge). Ann Parasit Hum Comp. 1933;11:287-96.

6. Schwetz J. Sur des Leucocytozoon trouvés chez divers oiseaux de l'Afrique Centrale. CR Hebd Mem Soc Biol. 1935;118:818-21. 
7. Valkiūnas G, lezhova TA, Carlson JS, Sehgal RNM. Two new Trypanosoma species from African birds, with notes on the taxonomy of avian trypanosomes. J Parasitol. 2011;97:924-30.

8. Chavatte JM, Okumura C, Landau I. Haematozoa of the great blue turacos, Corythaeola cristata (Vieillot, 1816) (Aves: Musophagiformes: Musophagidae) imported to Singapore Jurong Bird Park with description and molecular characterisation of Haemoproteus (Parahaemoproteus) minchini new species (Apicomplexa: Haemosporidia: Haemoproteidae). Raffles Bull Zool. 2017:65:325-40.

9. Gjerde B, Vikøren T, Hamnes IS. Molecular identification of Sarcocystis halieti n. sp., Sarcocystis lari and Sarcocystis truncata in the intestine of a white-tailed sea eagle (Haliaeetus albicilla) in Norway. Int J Parasit Paras Wildl. 2017;7:1-11.

10. Dubey JP, Sykes JE, Shelton GD, Sharp N, Verma SK, Calero-Bernal R, et al Sarcocystis caninum and Sarcocystis svanai n. sp. (Apicomplexa: Sarcocystidae) associated with severe myositis and hepatitis in the domestic dog (Canis familiaris). J Eukaryot Microbiol. 2015;62:307-17.

11. Kutkienè L, Prakas P, Sruoga A, Butkauskas D. The mallard duck (Anas platyrhynchos) as intermediate host for Sarcocystis wobeseri sp. nov. from the barnacle goose (Branta leucopsis). Parasitol Res. 2010;107:879-88.

12. Mugridge NB, Morrison DA, Johnson AM, Luton K, Dubey JP, Votýpka J, et al. Phylogenetic relationships of the genus Frenkelia: a review of its history and new knowledge gained from comparison of large subunit ribosomal ribonucleic acid gene sequences. Int J Parasitol. 1999:29:957-72.

13. Gjerde B. Molecular characterisation of Sarcocystis rileyi from a common eider (Somateria mollissima) in Norway. Parasitol Res. 2014;113:3501-9.

14. Gjerde B. Phylogenetic relationships among Sarcocystis species in cervids, cattle and sheep inferred from the mitochondrial cytochrome c oxidase subunit I gene. Int J Parasitol. 2013;43:579-91.

15. Gjerde B. Sarcocystis species in red deer revisited: with a re-description of two known species as Sarcocystis elongata n. sp. and Sarcocystis truncata n. sp. based on mitochondrial cox1 sequences. Parasitology. 2014;141:441-52.

16. Katoh K, Standley DM. MAFFT multiple sequence alignment software version 7: improvements in performance and usability. Mol Biol Evol. 2013;30:772-80.

17. Kumar S, Stecher G, Li M, Knyaz C, Tamura K. MEGA X: Molecular evolutionary genetics analysis across computing platforms. Mol Biol Evol. 2018;35:1547-9.

18. ICZN (International Commission on Zoological Nomenclature). Amendment of articles 8, 9, 10, 21 and 78 of the International Code of Zoological Nomenclature to expand and refine methods of publication. Bull Zool Nomen. 2012;69:161-9.

19. Pan J, Ma C, Huang A, Ye Y, Zeng H, Deng S, et al. Morphological and molecular characterization of Sarcocystis wenzeli in chickens (Gallus gallus) in China. Parasite Vectors. 2020;13:512-8.

20. Levine ND. The taxonomy of Sarcocystis (Protozoa, Apicomplexa) species. J Parasitol. 1986;72:372-82.

21. Olias P, Gruber AD, Kohls A, Hafez HM, Heydorn AO, Mehlhorn H, et al. Sarcocystis species lethal for domestic pigeons. Emerg Infect Dis. 2010;16:497-9.

22. Olias P, Olias L, Krucken J, Lierz M, Gruber AD. High prevalence of Sarcocystis calchasi sporocysts in European Accipiter hawks. Vet Parasitol. 2011;175:230-6.
23. Prakas P, Kutkienè L, Sruoga A, Butkauskas D. Sarcocystis sp. from the herring gull (Larus argentatus) identity to Sarcocystis wobeseri based on cyst morphology and DNA results. Parasitol Res. 2011;109:1603-8.

24. Prakas P, Butkauskas D, Švažas S, Juozaitytè-Ngugu E, Stanevičius V. Morphologic and genetic identification of Sarcocystis fulicae n. sp. (Apicomplexa: Sarcocystidae) from the Eurasian coot (Fulica atra). J Wildl Dis. 2018:54:765-71.

25. Mayr SL, Maier K, Müller J, Enderlein D, Gruber AD, Lierz M. Accipiter hawks (Accipitridae) confirmed as definitive hosts of Sarcocystis turdusi, Sarcocystis cornixi and Sarcocystis sp. ex Phalacrocorax carbo. Parasitol Res. 2016;115:3041-7.

26. Kutkienè L, Prakas P, Sruoga A, Butkauskas D. Description of Sarcocystis anasi sp. nov. and Sarcocystis albifronsi sp. nov. in birds of the order Anseriformes. Parasitol Res. 2012;110:1043-6.

27. Prakas P, Liaugaudaitė S, Kutkienè L, Sruoga A, Švažas S. Molecular identification of Sarcocystis rileyi sporocysts in red foxes (Vulpes vulpes) and raccoon dogs (Nyctereutes procyonoides) in Lithuania. Parasitol Res. 2015;114:1671-6

28. Moré G, Maksimov A, Conraths FJ, Schares G. Molecular identification of Sarcocystis spp. in foxes (Vulpes vulpes) and raccoon dogs (Nyctereutes procyonoides) from Germany. Vet Parasitol. 2016;220:9-14.

29. El-Morsey A, El-Seify M, Desouky ARY, Abdel-Aziz MM, El-Dakhly KM, Kasem S, et al. Morphologic and molecular characteristics of Sarcocystis atraii n. sp. (Apicomplexa: Sarcocystidae) infecting the common coot (Fulica atra) from Egypt. Acta Parasitol. 2015;60:691-9.

30. El-Morsey A, El-Seify M, Desouky AY, Abdel-Aziz MM, Sakai H, Yanai T. Sarcocystis chloropusae (Protozoa: Sarcocystidae) n. sp. from the common moorhen (Gallinula chloropus) from Egypt. Parasitology. 2015;142:1063-5.

31. Clubb SL, Frenkel JK. Sarcocystis falcatula of opossums: transmission by cockroaches with fatal pulmonary disease in psittacine birds. J Parasitol. 1992;78:116-24.

32. Prakas P, Butkauskas D, Juozaitytè-Ngugu E. Molecular identification of four Sarcocystis species in the herring gull, Larus argentatus, from Lithuania. Parasite Vectors. 2020;13:1-6.

33. Prakas P, Kutkiené L, Butkauskas D, Sruoga A, Žalakevičius M. Description of Sarcocystis lari sp. n. (Apicomplexa: Sarcocystidae) from the great blackbacked gull, Larus marinus (Charadriiformes: Laridae), on the basis of cyst morphology and molecular data. Folia Parasitol. 2014;61:11-7.

34. Kutkienè L, Prakas P, Sruoga A, Butkauskas D. Identification of Sarcocystis rileyi from the mallard duck (Anas platyrhynchos) in Europe: Cyst morphology and results of DNA analysis. Parasitol Res. 2010;108:709-14.

35. Wilson TM, Sousa SK, Paludo GR, de Melo CB, Llano HA, Soares RM, Castro MB. An undescribed species of Sarcocystis associated with necrotizing meningoencephalitis in naturally infected backyard chickens in the Midwest of Brazil. Parasit Int. 2020;102098.

\section{Publisher's Note}

Springer Nature remains neutral with regard to jurisdictional claims in published maps and institutional affiliations.

Ready to submit your research? Choose BMC and benefit from

- fast, convenient online submission

- thorough peer review by experienced researchers in your field

- rapid publication on acceptance

- support for research data, including large and complex data types

- gold Open Access which fosters wider collaboration and increased citations

- maximum visibility for your research: over $100 \mathrm{M}$ website views per year

At BMC, research is always in progress.

Learn more biomedcentral.com/submissions 